\title{
Reservoir hosts for Gyrodactylus salaris may play a more significant role in epidemics than previously thought
}

Giuseppe Paladini ${ }^{*}$, Haakon Hansen², Chris F Williams ${ }^{3}$, Nick GH Taylor ${ }^{4}$, Olga L Rubio-Mejía ${ }^{1}$, Scott J Denholm², Sigurd Hytterød ${ }^{1}$, James E Bron ${ }^{1}$ and Andrew P Shinn ${ }^{1,6}$

\begin{abstract}
Background: Gyrodactylus salaris Malmberg, 1957 has had a devastating impact on wild Norwegian stocks of Atlantic salmon Salmo salar L., and it is the only Office International des Epizooties (OIE) listed parasitic pathogen of fish. The UK is presently recognised as G. salaris-free, and management plans for its containment and control are currently based on Scandinavian studies. The current study investigates the susceptibility of British salmonids to $G$. salaris, and determines whether, given the host isolation since the last glaciation and potential genetic differences, the populations under test would exhibit different levels of susceptibility, as illustrated by the parasite infection trajectory over time, from their Scandinavian counterparts.

Methods: Populations of S. salar, brown trout Salmo trutta L., and grayling Thymallus thymallus (L.), raised from wild stock in UK government hatcheries, were flown to Norway and experimentally challenged with a known pathogenic strain of G. salaris. Each fish was lightly anaesthetised and marked with a unique tattoo for individual parasite counting. A single Norwegian population of S. salar from the River Lærdalselva was used as a control. Parasite numbers were assessed every seven days until day 48 and then every 14 days.

Results: Gyrodactylus salaris regularly leads to high mortalities on infected juveniles $S$. salar. The number of G. salaris on British S. salar rose exponentially until the experiment was terminated at 33 days due to fish welfare concerns. The numbers of parasites on S. trutta and T. thymallus increased sharply, reaching a peak of infection on days 12 and 19 post-infection respectively, before declining to a constant low level of infection until the termination of the experiment at 110 days.

Conclusions: The ability of S. trutta and T. thymallus to carry an infection for long periods increases the window of exposure for these two hosts and the potential transfer of $G$. salaris to other susceptible hosts. This study demonstrates that $G$. salaris can persist on $S$. trutta for longer periods than previously thought, and that the role that $S$. trutta could play in disseminating $G$. salaris needs to be considered carefully and factored into management plans and epidemics across Europe.
\end{abstract}

Keywords: Parasite, Salmo salar, Atlantic salmon, Salmo trutta, Brown trout, Thymallus thymallus, Grayling, Susceptibility, Monogenea, Pathogen

\footnotetext{
* Correspondence: paladini2000@yahoo.it

${ }^{1}$ Institute of Aquaculture, School of Natural Sciences, University of Stirling,

Stirling FK9 4LA, Scotland, UK

Full list of author information is available at the end of the article
}

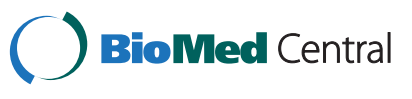

(c) 2014 Paladini et al.; licensee BioMed Central. This is an Open Access article distributed under the terms of the Creative Commons Attribution License (http://creativecommons.org/licenses/by/4.0), which permits unrestricted use, distribution, and reproduction in any medium, provided the original work is properly credited. The Creative Commons Public Domain Dedication waiver (http://creativecommons.org/publicdomain/zero/1.0/) applies to the data made available in this article, unless otherwise stated. 


\section{Background}

There are over 430 described species of Gyrodactylus, small ectoparasitic monogenean worms principally infecting fish [1]. While most species of Gyrodactylus cause relatively little harm to their hosts, other species such as Gyrodactylus salaris Malmberg, 1957 which is an OIE (Office International des Epizooties) listed pathogen, has had a notable catastrophic impact on Norwegian populations of juvenile Atlantic salmon, Salmo salar L. [2,3]. This parasite species was introduced to Norway on at least three separate occasions [4] and to date has been recorded from 49 Norwegian rivers, and the effects on the S. salar populations have necessitated extreme measures to control the parasite. These include the use of the biocide rotenone to kill-out complete river systems in order to remove the entire resident fish and, consequentially, the G. salaris population [3,5]. Given the impact that G. salaris has had in Scandinavia and Russia [6-9], Norway and the UK have surveillance programmes screening species of native salmonids that may serve as potential hosts for G. salaris. In the UK, this includes monitoring resident populations of potential hosts such as brown trout Salmo trutta L., Arctic charr Salvelinus alpinus (L.), grayling Thymallus thymallus (L.) and S. salar, whilst in Norway farmed rainbow trout Oncorhynchus mykiss (Walbaum) and both farmed and wild $S$. salar populations are screened.

The reports of G. salaris in Poland [10] and Italy [11] purportedly linked to the movement of salmonid stocks across borders emphasise the biosecurity risk this pathogen poses to countries with resident salmonid populations.

Great Britain and Northern Ireland (forming the United Kingdom), and some selected watersheds in Finland, are currently recognised G. salaris-free following the studies of Platten et al. [12], Shinn et al. [13], and on-going government-based surveillance programmes (www. scotland.gov.uk for Scotland; www.cefas.defra.gov.uk for England and Wales). Given the value of the UK's recreational $S$. salar and S. trutta fishing, which is worth in excess of $£ 350$ million [14], it is important that the UK's G. salaris-free status is upheld. Coarse and game angling figures for Scotland in 2010 were estimated at over $£ 100$ million (www.scotland.gov.uk), whilst recreational and commercial S. salar and S. trutta fisheries in England and Wales in 2001 (last figures available) had a capital value of $£ 130$ million (www.cefas.defra.gov.uk).

Other than S. salar, G. salaris has been demonstrated to colonise and reproduce on a large number of salmonids [15-21], and, under experimental studies, on a number of non-salmonid species as well [22-25]. The lack of clinical signs of disease on some of these hosts may allow G. salaris infections to go undetected. This is well demonstrated by the study of Paladini et al. [11], where the examination of formalin-preserved material in farm archives indicated that G. salaris had been in Italy on $O$. mykiss for at least nine years prior to discovery. Such asymptomatic hosts may represent a serious problem in that they can serve as reservoirs playing an important role in the epidemiology and dispersal of G. salaris across Europe [26-28].

Existing UK dispersion models [29] and management plans for the containment of G. salaris are based on the assumption that in the worst-case scenario, British stocks of $S$. salar would be vulnerable to G. salaris and therefore at risk [30,31], as would all the salmonids within an area occupied by $S$. salar, which may act as reservoir hosts. No assumptions are made for other salmonids in the UK. Although S. trutta have a widespread distribution throughout England and Wales, it is mainly towards the west of the country where their occurrence overlaps with the natural habitat range of wild S. salar. Likewise, many $O$. mykiss aquaculture sites in the UK are in close proximity to resident $S$. trutta populations; it is assumed that British populations of S. trutta would be entirely resistant to $G$. salaris infection and unaffected [15,32,33]. The natural distribution of $T$. thymallus populations in the UK overlaps with both $S$. salar and S. trutta. From previous studies, it is suggested that $T$. thymallus would be relatively resistant to G. salaris infection, although it has been demonstrated that the parasite can survive and reproduce on Scandinavian T. thymallus for 143 days [16,34].

Following models determined for Scandinavian populations of S. trutta and T. thymallus [3], these hosts are thought to harbour low-level infections of G. salaris for a few weeks, not displaying the exponential increase in numbers seen on $S$. salar, although they may act as reservoirs of infection. Native UK stocks of S. trutta and T. thymallus, however, have been separated from their Scandinavian counterparts since the last period of glaciation [35-37], and their relative patterns of susceptibility and/or resistance may therefore differ from those predicted from Norwegian studies. Assumptions that UK $S$. salar are susceptible to G. salaris are derived from a few earlier studies which tested the susceptibility of two Scottish populations of S. salar (i.e. from the Rivers Shin and Conon) to G. salaris originating from the River Figga, county Nord-Trøndelag, Norway [31,38,39]. The experimental exposure of other British salmonids (i.e. S. trutta, T. thymallus, etc.) to G. salaris has not been conducted to date.

The current study determines for the first time the responses of different English and Welsh salmonids to a pathogenic strain of G. salaris and sets out to make a contribution, not only to existing UK national G. salaris management planning, but also to disease risk management across Europe. The findings from this study highlight the importance of reservoir hosts in the risk of establishment and spread of G. salaris, increasing its rapid spread and placing greater pressure on parasite 
detection and management approaches. The study also discusses the extent to which laboratory conditions might affect the results of infection experiments, and gauge whether extrapolation from existing results is appropriate for UK management policy.

\section{Methods}

All experimental procedures and husbandry practices involving animals were conducted in compliance with the Animals Scientific Procedures Act 1986 (Home Office Code of Practice. HMSO: London, January 1997), in accordance with EU regulation (EC Directive 86/609/EEC), and approved by the Animal Ethics and Welfare Committee of the University of Stirling, UK. The experimental work was also approved by the Norwegian Animal Research Authority (NARA).

\section{Origin of experimental salmonid populations}

Populations of S. salar, S. trutta and T. thymallus supplied for this study were obtained from registered Environment Agency fish farms located in England and Wales. Wild adult broodstock of each species were captured by means of electrofishing and transported live to hatchery facilities. The fish were subsequently held, stripped of eggs and milt, and the off-spring reared under the conditions described. This work was authorised and conducted by staff of the Environment Agency under the statutory duty to maintain, improve and develop fisheries in England and Wales.

\section{i) Salmo salar from the River Dee, Wales}

In 2010/2011, eggs from wild $S$. salar caught in the River Dee, northern Wales, were stripped, fertilised and reared to 0+ parr in the Environment Agency's (EA) Maerdy Hatchery, Corwen, Conwy, Wales (5259'18.18” N; $3^{\circ}$ 27'48.18" W). The eggs began hatching around midJanuary 2011. The fish were reared on ambient water (av. $2.7^{\circ} \mathrm{C}$ ) from the Afon Ceirw using a natural photoperiod regime and a $1 \%$ body wt day ${ }^{-1}$ daily feed ration (Skretting Nutra Parr 02). The fish had a mean total length of $67.0 \pm 0.2 \mathrm{~mm}$ and a mean weight of $3.4 \pm 0.3 \mathrm{~g}$ at the time they were transported to Norway.

\section{ii) Salmo trutta from the River Tyne, England}

In November 2010, adult S. trutta broodstock were collected from the River Rede, a tributary of the River Tyne, Northumberland, England. The ripe female fish were stripped and fertilised, and the eggs maintained at the EA's Kielder Hatchery ( $\left.55^{\circ} 14{ }^{\prime} 00.45^{\prime \prime} \mathrm{N} ; 2^{\circ} 34^{\prime} 39.69^{\prime \prime} \mathrm{W}\right)$. Egg hatching occurred over the period March to April 2011. The eggs and juvenile fish were maintained at ambient water temperatures $\left(0-18.5^{\circ} \mathrm{C}\right)$, with natural photoperiod conditions and a $0.1-2.8 \%$ body wt day ${ }^{-1}$ daily feed ration (Skretting Emerald Fry 00, 01 and 02 crumb) over a period of 303-316 days, until they were transported to Norway. The $0+$ parr had a mean total length of $85.2 \pm 0.5 \mathrm{~mm}$ and a mean weight of $4.45 \pm$ $0.4 \mathrm{~g}$ at the time of transportation.

\section{iii) Thymallus thymallus from the River Nidd, England} Thymallus thymallus broodstock originating from the River Nidd, Knaresborough, England were stripped and the eggs reared in the EA's Calverton Fish Farm (53 02'01.43" N; $\left.1^{\circ} 03^{\prime} 05.95^{\prime \prime} \mathrm{W}\right)$. Egg hatching began in April 2011. The fish were reared on borehole water (mean $10 \pm$ $1^{\circ} \mathrm{C}$ ) and a constant natural photoperiod (05.00-21.30 without adjustment). First ad libitum feed was Artemia salina for approximately two weeks, followed by a gradual weaning onto Coppens TroCo Crumble Top and Crumble HE feed. Throughout the rearing phase, the dried diet was supplemented by gamma-radiated chironomids. The $0+T$. thymallus had a mean total length of $111.7 \pm 0.7 \mathrm{~mm}$ and weight $12.7 \pm 0.5 \mathrm{~g}$ at the time of their transportation to Norway in January 2012.

\section{iv) Salmo salar from the River Lærdalselva, Norway, control group}

The $S$. salar juveniles (age 0+, mean total length $90.5 \pm$ $0.5 \mathrm{~mm}$, mean weight $5.5 \pm 0.5 \mathrm{~g}$ ) used as a control for this trial originated from the River Lærdalselva $\left(61^{\circ} 02^{\prime}\right.$ $\mathrm{N} ; 7^{\circ} 36^{\prime} \mathrm{W}$ ), western Norway, and were obtained from the Ljøsne hatchery, near Lærdal. The fish were reared on ground water, heated to $11^{\circ} \mathrm{C}$ during the first week post-hatching, and subsequently on heated ground water at $9^{\circ} \mathrm{C}$ for the rest of the culture period until their transfer to the Norwegian Veterinary Institute (NVI) in Oslo. Fish were fed ad libitum with a commercial pellet diet (Skretting Nutra Plus 01). The fish were transported to the NVI in oxygenated water, using the same methodology described in the section below ("Transportation of salmonids to Norway") to ensure similar conditions for both control and experimental fish. Upon arrival at the fish holding department, the fish were immediately transferred to a holding tank $(60 \times 60 \times 70 \mathrm{~cm})$ and acclimated in laboratory water at $11^{\circ} \mathrm{C}$ for seven days prior to the start of the experiment. A single tank of 10 fish was used during the trial.

\section{Transportation of salmonids to Norway}

In January 2012, $70 \mathrm{~S}$. salar originating from the Welsh River Dee, 70 S. trutta from the English River Tyne, and 70 T. thymallus from the English River Nidd were transported from Environment Agency fish farms to the secure research aquarium facility within the NVI in Oslo. Each population of fish was prepared by EA staff at the hatchery, by double-bagging the fish in oxygenated polyethylene bags and placing them on chill packs, to ensure a stable temperature during transportation. These were sealed in International Air Transport Association (IATA)-approved 
robust polystyrene boxes, each of which measured $65 \mathrm{~cm}$ (depth) $\times 58 \mathrm{~cm}$ (length) $\times 49 \mathrm{~cm}$ (width). The polystyrene boxes were then placed inside a double-walled cardboard box to ensure protection during transportation. The relevant permissions from the Chief Veterinary Officer in the UK and in Norway, from the Norwegian authorities (The Directorate for Nature Management and the Food Safety Authorities) and from the NVI, were obtained before the fish were shipped. The project was also monitored by senior government officials and fish biologists within Defra (Department of the Environment, Fisheries and Rural Affairs), London; the EA (Environment Agency), National Fisheries Laboratory, Brampton; and, at Cefas (Centre for Environment, Fisheries \& Aquaculture Science), Weymouth Laboratory, UK. The fish were transported using the specialist live animals courier, Gulf Agency Company (GAC) Logistics, through Manchester International airport to Gardermoen Airport, Oslo, Norway. Once a visual health inspection of the fish and their welfare by the onduty veterinary surgeon at Oslo had been made and were cleared as fit to continue their onward journey, the fish were transported immediately to the NVI, Oslo research facility. The fish, still within their plastic bags, were transferred to $0.6 \mathrm{~m}$ (diameter) $\times 0.7 \mathrm{~m}$ (depth) fibreglass tanks supplied with a constant $11 \pm 1^{\circ} \mathrm{C}$ water flow rate of $200 \mathrm{ml} \mathrm{min}^{-1}$ and additional aeration; the temperature of the water in the bags was allowed to adjust to that of the tank, before the bags were opened and the fish released. No fish were lost during the $6 \mathrm{~h}$ transportation exercise, i.e. from the time they were packed to the time they were released in their tanks at NVI. The fish were left to acclimate for a further seven days before the infection trial was started. The source of the water used within the aquarium was from the Oslo city domestic supply, which passes through a particle filter (Structural C-2160-F7 composite, 310 L) and an activated carbon filter (GAK 170) prior to use.

\section{Source of Gyrodactylus salaris used for the trial}

The G. salaris strain used in the experiment, i.e. mitochondrial haplotype A [4], was obtained from wild $S$. salar juveniles, sampled by electrofishing in the River Fusta, northern Norway (6554'9.57"N 13 9'50.92"E). This particular strain of G. salaris has previously been tested experimentally and shown to be pathogenic to $S$. salar [40].

\section{Gyrodactylus salaris infection procedure}

Thirty fish from each population were randomly selected, using the simple random sample (SRS) method [41], and then infected by transferring them to a static $30 \mathrm{~L}$ tank with aeration into which approximately 3,000 G. salaris had been added by gently scraping the excised fins of heavily infected aquarium-held fish. This approach has been used effectively in the past $[16,32,42]$ to ensure an infection of 50-80 parasites fish ${ }^{-1}$ over a $24 \mathrm{~h}$ exposure period, and it assumes that $50 \%$ of parasites will successfully transfer to the new host. Following the exposure period, each fish, which was tattooed with a unique mark using alcian blue $\left(40 \mathrm{mg} \mathrm{ml}^{-1}\right)$, was lightly anaesthetised in metacain Finquel ${ }^{\odot}$ Vet. $\left(50 \mathrm{mg} \mathrm{L}^{-1}\right)$, and the total number of G. salaris on each fin and body zone was counted under a Leica MZ7.5 dissecting microscope at $\times 4$ magnification. This anaesthetic has also been used in previous experiments [43,44], as it does not affect Gyrodactylus survival. Alcian blue marking was preferred as a rapid, reliable, easy, and long-lasting method [45], rather than fin clipping, as fins are the preferred microhabitat of $G$. salaris [3].

Each fish was then randomly assigned to one of three experimental tanks (10 L circular; flow-through $200 \mathrm{ml}$ $\mathrm{min}^{-1}$ ). Each population was tested in triplicate (each replicate $n=10$ juvenile fish), with the exception of the River Lærdalselva Norwegian S. salar control, which was already a standardised model previously tested in several trials by the same research aquarium, and for which only a single tank of 10 fish was infected. The S. trutta population, however, was highly aggressive when separated into the three small tanks of 10 fish each. For this reason, a single $0.6 \times 0.7 \mathrm{~m}$ fibreglass tank $(30 \mathrm{~L}$; flow-through $200 \mathrm{ml}$ $\mathrm{min}^{-1}$ ) containing all 30 fish was used for the S. trutta trial.

Seven days later, each tank of fish was anaesthetised and the number of G. salaris on each individually marked fish was determined by manual counting parasites with the aid of a Leica MZ7.5 stereo-microscope. The fish were sampled approximately every seven days thereafter until day 48 and then every 14 days. The fish were fed with a commercial pelleted diet (Skretting Nutra Parr 1.8) once a week.

\section{Results}

The dynamics of G. salaris infection on each of the three salmonid populations originating from England and Wales were compared against an infection of G. salaris on Norwegian S. salar over trials lasting up to 110 days. The parasite numbers on each individually marked fish and the mean of each replicate are shown in Figures 1 and 2, while the mean parasite burden and the range for each population of fish, at each sampling time point, are presented in Table 1. The initial G. salaris infection burdens, 24 h post-infection (p.i.), were: 87.0 parasites fish $^{-1}$ (28-215) on the Welsh S. salar from the River Dee; 79.6 parasites fish $^{-1}(46-108)$ on the Norwegian control; 59.7 parasites fish ${ }^{-1}(32-107)$ on S. trutta; and, 59.8 parasites fish $^{-1}$ (28-146) on T. thymallus (see Table 1).

The results obtained demonstrate that the Welsh $S$. salar are highly susceptible to G. salaris infection (mean intensity $\sim 1,742$ parasites fish ${ }^{-1}$ in $33 \mathrm{~d}$; see Figure $1 \mathrm{~A}$ ), 


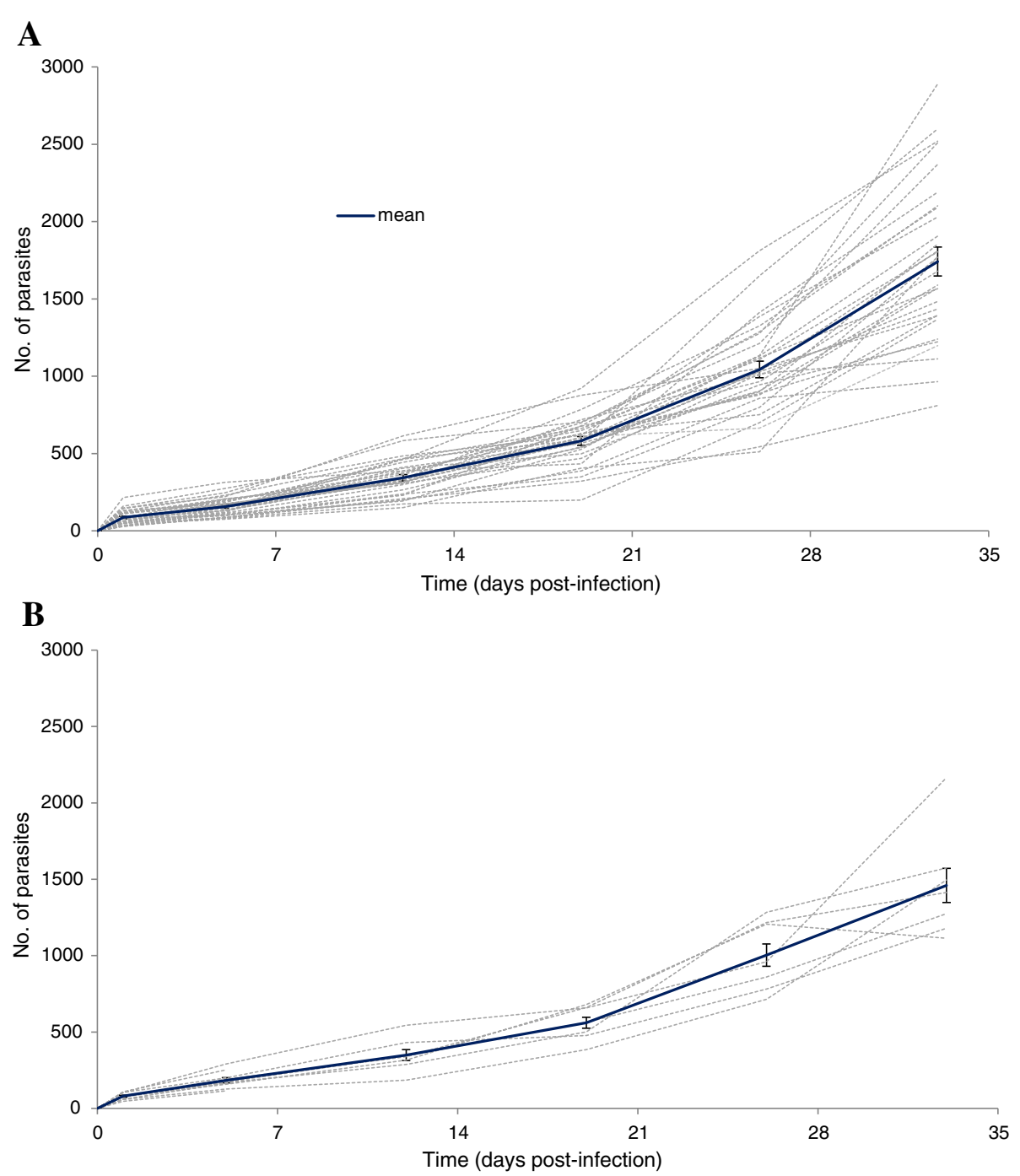

Figure 1 Gyrodactylus salaris Malmberg, 1957 on two strains of Atlantic salmon Salmo salar L. Experimental infection of G. salaris (Fusta strain, haplotype A) on (A) S. salar ( $n=30$; three replicates of 10 fish each), from the River Dee in Wales, UK; and (B) the control group of S. salar $(n=10)$ from the River Lærdalselva, Norway. The growth on the two hosts (Welsh and Norwegian S. salar populations) is shown on the same scale for direct comparison. Grey dotted lines represent the number of parasites assessed on each individually marked fish; mean intensity of infection is shown in blue line, including standard error of the mean (SEM).

when compared against the Norwegian control tank of fish which had a mean infection intensity of $\sim 1,460$ parasites fish ${ }^{-1}$ over the same time period (Figure 1B). These fish were unable to initiate a successful defence against the parasite and the experiment was terminated on day 33 p.i. due to concerns for fish welfare, following the classical initial symptoms of parasitic disease, e.g. flashing, eroded fins, increased mucus production giving the fish a grey colouration.

The infections of G. salaris on the S. trutta from the River Tyne peaked after $\sim 12$ days (mean intensity 145.9 parasites fish $^{-1}$; Figure 2A), whilst those on the River Nidd T. thymallus peaked after $\sim 19$ days (mean intensity 252.6 parasites fish ${ }^{-1}$; Figure $2 \mathrm{~B}$ ). Thereafter, the extent of parasite infection decreased on both hosts. The G. salaris infection had almost disappeared on both sets of fish by the time the experiment was terminated on day 110 p.i. The population of G. salaris on three of the 30 T. thymallus that were tested appeared to display two peaks of infection on days 19 (av. $238.0 \pm 49.4$ parasites fish $^{-1}$ ) and 33 (av. $250.3 \pm 62.2$ parasites fish ${ }^{-1}$ ) p.i., with a subsequent steady decrease in parasite numbers from day 26 p.i. until the experiment was terminated on day 110 p.i. Salmo trutta showed a similar response, with three $S$. trutta displaying two peaks of infection on days 12 (av. $119.3 \pm 14.2$ parasites fish ${ }^{-1}$ ) and 26 (av. 83.0 \pm 10.1 parasites fish $^{-1}$ ) p.i., with a subsequent steady decrease in numbers from day 19 p.i. onwards. By day 110 

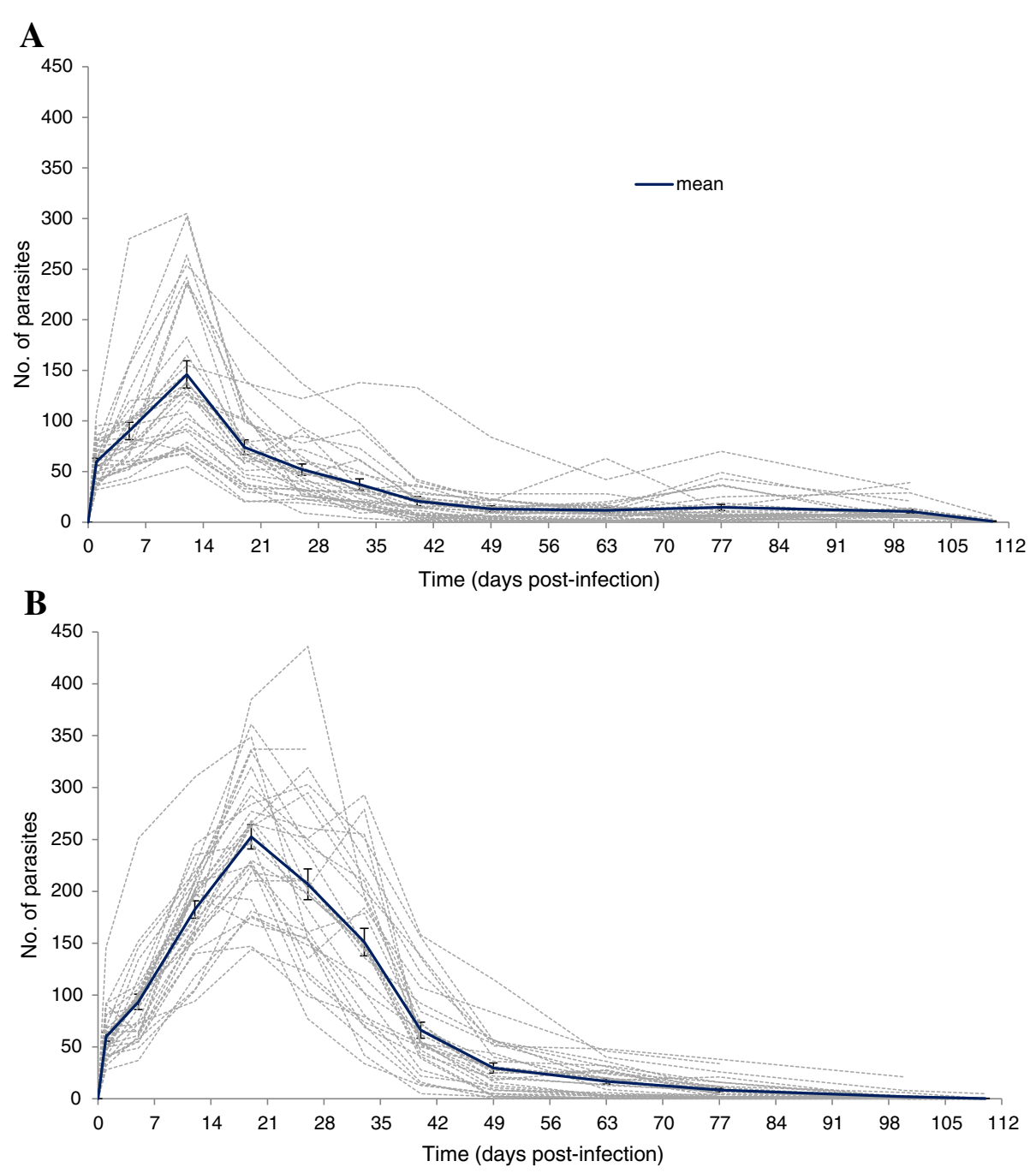

Figure 2 Gyrodactylus salaris Malmberg, 1957 on brown trout Salmo trutta L. and grayling Thymallus thymallus (L.). Experimental infection of G. salaris (Fusta strain, haplotype A) on a population of (A) S. trutta ( $\mathrm{n}=30)$, from the River Tyne in England, UK; and (B) T. thymallus ( $n=30$; three replicates of 10 fish each), from the River Nidd in England, UK. The growth on S. trutta and T. thymallus is shown on the same scale for direct comparison. Grey dotted lines represent the number of parasites assessed on each individually marked fish; mean intensity of infection is shown in blue line, including standard error of the mean (SEM).

p.i., the infection on most fish had disappeared; only seven of the S. trutta were still infected (range 1-6 parasites fish ${ }^{-1}$; see Figure 2A), and only two of the 30 T. thymallus were infected (i.e. one with one parasite, the other with five G. salaris; see Figure 2B).

The experiment was terminated on day 110 p.i. out of welfare concerns for the fish and that sufficient data had been collected to inform the likely response of these populations of fish to G. salaris (haplotype A) infection. Prolonging the infection was unlikely to result in additional information and would incur additional unnecessary operational costs.

A power outage on day 69 p.i., which resulted in an overnight temporary cessation in water flow to the $T$. thymallus and S. trutta tanks, resulted in the loss of five
S. trutta and five T. thymallus. In the following two parasite counts, an increase in parasite number was observed on 23 of the $30 \mathrm{~S}$. trutta and on two of the $30 \mathrm{~T}$. thymallus. The parasites on the dead fish were counted immediately on the discovery of the fish mortalities, and were included in the total count. After the power outage, the number of parasites on each of the five dead $S$. trutta were counted following their removal. Only the parasite number on one fish had increased (i.e. from one to eight G. salaris fish $^{-1}$ ), whilst on the other four fish the number had decreased (i.e. from 63 to 12; from 28 to 11 ; from 17 to two; and from 16 to two G. salaris fish ${ }^{-1}$ ). The number of G. salaris on the dead T. thymallus were also determined and in each case the number of parasites had decreased. 
Table 1 Intensity of Gyrodactylus salaris Malmberg, 1957 infection on Salmo salar L. from the River Dee, Wales and from the Laerdalselva, Norway (control group), from Salmo trutta L. from the River Tyne, England and from Thymallus thymallus (L.) from the River Nidd, England

\begin{tabular}{|c|c|c|c|c|}
\hline Time points (days) & $\begin{array}{l}\text { Salmo salar } \\
\text { (R. Dee, Wales) }\end{array}$ & $\begin{array}{l}\text { Salmo salar (control) } \\
\text { Laerdalselva, Norway }\end{array}$ & $\begin{array}{l}\text { Salmo trutta } \\
\text { (R. Tyne, England) }\end{array}$ & $\begin{array}{l}\text { Thymallus thymallus } \\
\text { (R. Nidd, England) }\end{array}$ \\
\hline 1 & $87.0 \pm 8.2(28-215)$ & $79.6 \pm 6.6(46-108)$ & $59.7 \pm 3.5(32-107)$ & $59.8 \pm 4.3(28-146)$ \\
\hline 5 & $157.4 \pm 11.2(76-314)$ & $183.4 \pm 17.0(114-291)$ & $90.1 \pm 8.5(39-280)$ & $93.4 \pm 7.5(37-251)$ \\
\hline 12 & $343.6 \pm 21.3(151-615)$ & $349.1 \pm 35.8(184-544)^{a}$ & $145.9 \pm 13.4(55-305)$ & $182.5 \pm 8.4(94-310)$ \\
\hline 19 & $581.6 \pm 28.6(200-923)$ & $560.4 \pm 35.3(385-679)$ & $74.0 \pm 7.2(20-191)$ & $252.6 \pm 11.7(144-385)$ \\
\hline 26 & $1043.5 \pm 54.1(511-1812)$ & $1003.1 \pm 73.2(714-1284)$ & $52.0 \pm 5.6(9-137)$ & $206.7 \pm 14.8(77-436)$ \\
\hline 33 & $1741.5 \pm 93.1(810-2890)$ & $1459.7 \pm 111.5(1114-2165)$ & $37.3 \pm 5.5(4-138)$ & $151.1 \pm 13.3(34-293)^{d}$ \\
\hline 40 & - & - & $20.7 \pm 4.4(1-133)$ & $66.1 \pm 7.8(5-158)$ \\
\hline 49 & - & - & $13.1 \pm 2.8(0-84)$ & $29.7 \pm 4.9(0-115)$ \\
\hline 63 & - & - & $11.8 \pm 2.4(0-63)$ & $16.9 \pm 2.7(0-48)$ \\
\hline 77 & - & - & $14.5 \pm 3.0(0-70)^{b}$ & $8.5 \pm 1.9(0-38)^{\mathrm{e}}$ \\
\hline 100 & - & - & $10.6 \pm 1.8(0-39)^{c}$ & $2.1 \pm 0.8(0-21)^{f}$ \\
\hline 110 & - & - & $0.9 \pm 0.3(0-6)$ & $0.3 \pm 0.2(0-5)$ \\
\hline
\end{tabular}

Footnotes: Fish mortalities throughout the duration of the experiment. Parasite numbers were assessed on dead individuals.

Control S. salar: ${ }^{\text {a }}$ three dead fish not linked with G. salaris infection.

Salmo trutta: ${ }^{b}$ five dead fish due to power outage and temporary cessation in water flow on day $69 ;{ }^{c}$ further two dead fish due to the stress derived by the previous power outage.

Thymallus thymallus: ${ }^{d}$ one dead fish; ${ }^{e}$ further five dead fish due to power outage and temporary cessation in water flow on day $69 ;{ }^{f}$ further six dead fish due to the stress derived by the previous power outage.

The mean intensity \pm standard error of the mean (SEM) and the range in parentheses are presented for each time point post-infection (p.i.) and host.

The remaining pools of fish from the Rivers Dee $(\mathrm{n}=$ 40), Lærdalselva $(\mathrm{n}=10)$, Nidd $(\mathrm{n}=40)$ and Tyne $(\mathrm{n}=$ 10) that were brought in for the experiment but not subjected to experimental infection were maintained in separate tanks throughout the duration of the experimental trial. There were no mortalities in these tanks of fish over the 110 day trial period, and were confirmed free of an existing Gyrodactylus infection by visual examination.

Figure 3 shows the average distribution of G. salaris across the body and fins of each fish species throughout the experimental infection, and the graphs illustrate the importance of the fins as the preferred site of infection. The distribution of G. salaris on the two S. salar populations (Figure $3 \mathrm{~A}-\mathrm{B}$ ) suggests that the pectoral, caudal and pelvic fins are the preferred sites of colonisation, where the parasites are evenly distributed over time. The number of G. salaris on the Welsh S. salar was also seen to increase on the eyes throughout the duration of the trial, although not given as a specific category in Figure 3A. The distribution of G. salaris on S. trutta and T. thymallus indicates that parasites have a preference towards occupying the caudal fin during the first 19 days of infection, and following this period, pectoral fins are the preferred site of colonisation on both hosts (Figure 3C-D). After 19 days, the parasite numbers on $S$. trutta increased also on the pelvic fins, whilst the third most colonised body part for T. thymallus was the dorsal fin (Figure 3C-D).

\section{Discussion}

The infection of Welsh S. salar from the River Dee followed the expected infection trajectory with fish being highly susceptible to G. salaris infection. The trial found infections rapidly rose to $\sim 1,742$ parasites per fish in just 33 days. This finding is in close agreement with the response of $S$. salar (Atlantic strain) populations from elsewhere, including those tested from Scotland [31].

The increasing number of G. salaris observed on the eyes of the Welsh $S$. salar may be explained in that the eye represents an immunologically-privileged site $[46,47]$ and therefore the immune response to parasitic infection is believed to be lower on this organ [48]. The observed increase in the number of parasites may reflect parasites moving away from skin and fin sites to avoid the host's immune response, as has been suggested by other researchers [49-51].

The River Tyne S. trutta and the River Nidd T. thymallus were both responsive to G. salaris infection, with parasite numbers increasing and then subsequently declining to near extinction over the 110 days the trial was run.

Differences in the mean length of fish between species may affect parasite infection dynamics, as shown in other gyrodactylid model systems [52,53]. Although every attempt was made to provide similar sized fish from the available stocks for the start of the experimental trial and although there were differences in the length 


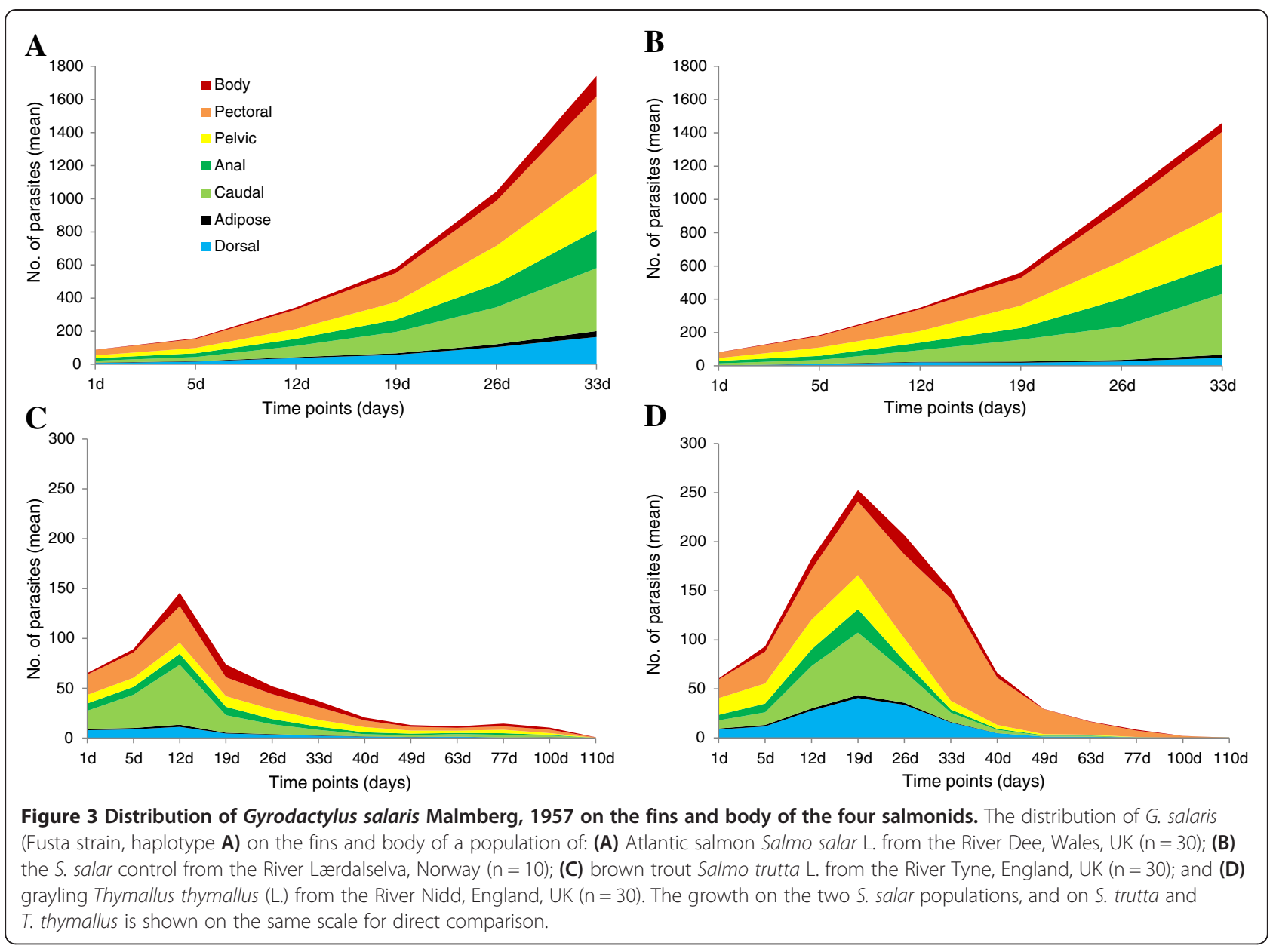

and weights of each host, the infection protocol resulted in similar starting infections (see Figure 2A-B; Table 1). The intra-variability in G. salaris infections shown by $S$. trutta and T. thymallus may be due to different susceptibilities within the same host species [54]. The different initial infection numbers seen on the four hosts may be due to the individual behaviour of the fish during the infection period, although all the fish were treated the same. There were no mortalities as a direct result of parasitic infection and there was no discernible change in fish behaviour. The $S$. trutta population was initially divided into three small groups of 10 fish each, but soon after the split, the fish showed highly aggressive behaviour causing losses of half of the population. The aggressive behaviour, including biting, chasing and fighting, in juvenile $S$. trutta has been previously documented [55] as a consequence of territoriality and competition for food in confined spaces. It is not clear, however, why aggression levels in the current trial increased dramatically with fish being split up into smaller groups, since the fish densities in the three small tanks with 10 fish each and in the single large tank containing 30 fish were the same. The lack of habitat enrichment within the tanks, i.e. features within which fish can hide or avoid aggression, may be a causal factor independent of stocking density.

The distribution of G. salaris on S. trutta and T. thymallus changed over time from the caudal fin in the first three weeks post infection, to the pectoral fins thereafter (Figure 3C-D). The shift in host sites may be a result from localised host immune reactions induced by the parasites [51,56].

Five S. trutta and five T. thymallus were lost due to a power outage on day 69 p.i., which temporarily stopped the water flow in the tanks. The stress imposed on the remaining fish, coupled with the possibility of parasite transfer from dead hosts due to fish cannibalism [57], are possible explanations for the observed small increase in parasite numbers on day 77 p.i. There was no marked variance, however, in parasite numbers between dead and live fish, therefore the average G. salaris intensity of infection on S. trutta and T. thymallus in the following counts are not considered to be due to parasites moving off the dead fish and colonising new hosts.

Although every precaution was taken to ensure fish welfare was upheld throughout the duration of the susceptibility trial, the level of stress placed upon each 
population of fish during their transportation from the UK to Norway and in their experimental tanks is not known. Whilst the 110 day period of infection may not accurately reflect how British populations of $S$. trutta in the wild would respond to G. salaris, if introduced into the UK, the trial has shown that the River Tyne population of $S$. trutta are able to manage infections and keep numbers to a low level, even under periods of anticipated stress. Although there were no G. salaris-related S. trutta or T. thymallus mortalities, the concern is that populations of these two species under stress may extend the period over which individuals can carry an infection of G. salaris, therefore, increasing the possible risk of parasite transfer to other fish species. Currently, 18 G. salaris mitochondrial haplotypes (strains) have been identified by cytochrome oxidase I (COI) analysis [4,11,58-64]. Most of the previous experimental findings (see Table 2), however, are based on studies using G. salaris "originating" from the River Lierelva (Norway), i.e. haplotype F according to the study of Hansen et al. [4]. This haplotype has been commonly found on O. mykiss and S. salar $[4,58]$, and is also found on Arctic charr [64]. The study conducted by Bakke and MacKenzie [31] on Scottish S. salar, however, used a strain of G. salaris originating from the River Figga, Norway (Table 2), most likely corresponding to haplotype A (though not stated, this is interpreted from the map of haplotype distribution presented in Hansen et al. [4]). The strain of G. salaris used in the current study was derived from the River Fusta in the Vefsna region of Norway and corresponds to haplotype A, which has been demonstrated to be pathogenic to a Norwegian strain of $S$. salar [40].

\section{The importance of including brown trout Salmo trutta in the current trial}

One of the most interesting findings from the current trial arises from the infection of G. salaris on the population of S. trutta from the River Tyne. Prior to this study, S. trutta had been considered resistant to G. salaris infection. Jansen and Bakke [15], for example, infecting both individual and pooled (i.e. 50 fish per tank) samples of S. trutta with the strain of G. salaris from the River Lierelva (haplotype F), found that fish could carry an infection for up to 50 days. The current study found that when a pool of S. trutta were each given an initial infection of $\sim 70 \mathrm{G}$. salaris per fish, then the $G$. salaris infections on these fish persisted for at least 110 days, when the experiment was terminated. Of these, seven of the 30 fish were still infected with between one and six parasites each.

Salmo trutta parr naturally infected with G. salaris at low intensities have been reported by a number of authors [68-71]. The studies by Tanum [68] and Mo [69] also demonstrated that $S$. trutta were able to maintain their G. salaris infections when cohabited with infected
S. salar. A study by Bakke et al. [32] found that S. trutta exposed to infected fins of $S$. salar for $24 \mathrm{~h}$ and subsequently held in isolation eliminated their G. salaris infections in less than two weeks, suggesting that they could be innately resistant. Harris et al. [33] also considered S. trutta to be innately resistant to G. salaris when, after exposing groups of fish to infected $S$. salar fins for $24 \mathrm{~h}$, the fish lost their infections within 42 days. In a survey by Jansen and Bakke [15], anadromous S. trutta from the River Lierelva were cohabited with heavily infected $S$. salar from the Lierelva for five days, and then either isolated and held individually or maintained as a group. In both cases, the infections of $G$. salaris on the $S$. trutta persisted for approximately 49 days p.i. In a repeat trial using a stock of S. trutta from Lake Tunhovd, Norway, the infection of $G$. salaris on the isolated $S$. trutta $(\mathrm{n}=21)$ persisted for 28 days, whilst the infection on grouped fish $(n=21)$ lasted for 21 days p.i. These trials suggested that $S$. trutta can serve as a carrier for disseminating the parasite, although it is not able to support an infection with G. salaris for long periods [15].

The current study, however, found that English $S$. trutta can carry an infection of G. salaris for at least 110 days, and this finding appears to contradict those of previous studies $[15,32,33]$. This might be explained by genetic differences between each population of S. trutta, as also shown in a study [72] using three-spined sticklebacks, Gasterosteus aculeatus L., artificially infected with Gyrodactylus gasterostei Gläser, 1974, or by a potential different pathogenicity between G. salaris haplotypes (Table 2), i.e. Jansen and Bakke [15], Bakke et al. [32] and Harris et al. [33] who used haplotype F, while the current experiment used haplotype A. Additional studies, therefore, are required to elucidate this further.

\section{The importance of including grayling Thymallus thymallus in the current trial}

English and Welsh grayling are commonly infected with Gyrodactylus thymalli Žitňan, 1960, a congener morphologically and genetically similar to or conspecific with $G$. salaris [60,61,67,73-75]. Previous experimental studies, however, suggested that the Lierelva strain of G. salaris (haplotype F) is unable to show high pathogenicity on the Scandinavian T. thymallus, although infections could persist for anything between 35 [16] and 143 days [34]. In both studies, the experiments were terminated with a low number of parasites still on their hosts. Likewise, the infections of G. salaris on T. thymallus in the current study were not completely outside the expected response, with a low level of parasites remaining on fish for the duration of the 110-day experiment. Only two out of the $30 \mathrm{~T}$. thymallus, however, were still infected at the end of the trial. The finding that English T. thymallus can carry infections for long periods of time gives cause for concern in that they 
Table 2 Gyrodactylus salaris Malmberg, 1957 haplotypes used in previous experiments ascertaining the susceptibility of different strains of Salmo salar L. ( $A$ = Atlantic strain; B = Baltic strain)

\begin{tabular}{|c|c|c|c|c|c|}
\hline Reference & $\begin{array}{l}\text { Origin of S. salar } \\
\text { tested in previous } \\
\text { studies (rivers) }\end{array}$ & $\begin{array}{l}\text { Origin of the } \\
\text { G. salaris strain }\end{array}$ & $\begin{array}{l}\text { G. salaris } \\
\text { haplotype }\end{array}$ & $\begin{array}{l}\text { Parasite } \\
\text { population } \\
\text { dynamics }\end{array}$ & Host response $^{1}$ \\
\hline \multirow[t]{2}{*}{ Bakke [53] } & $\begin{array}{l}\text { A: Alta, Lone, } \\
\text { Drammenselva } \\
\text { and Lierelva } \\
\text { (Norway) }\end{array}$ & R. Drammenselva & $\mathrm{F}$ & exponential growth & susceptible \\
\hline & B: Neva (Russia) & R. Drammenselva & $\mathrm{F}$ & declining after 3 weeks & responding \\
\hline $\begin{array}{l}\text { Bakke and MacKenzie } \\
\text { [31] }\end{array}$ & $\begin{array}{l}\text { A: Conon and Shin } \\
\text { (Scotland) and } \\
\text { Lierelva (Norway) }\end{array}$ & R. Figga & $A^{*}$ & exponential growth & susceptible \\
\hline \multirow[t]{2}{*}{ Bakke et al. [30] } & A: Alta and Lone (Norway) & R. Drammenselva & $\mathrm{F}$ & exponential growth & susceptible \\
\hline & B: Neva (Russia) & R. Drammenselva & $\mathrm{F}$ & declining after 3 weeks & $\begin{array}{l}\text { innately } \\
\text { resistant } \\
\text { and responding }\end{array}$ \\
\hline Bakke et al. [65] & A: Akerselva (Norway) & unknown & unknown & exponential growth & susceptible \\
\hline \multirow[t]{3}{*}{ Bakke et al. [32] } & A: Alta (Norway) & R. Lierelva & $\mathrm{F}$ & exponential growth & susceptible \\
\hline & $\begin{array}{l}\text { } A \times \widehat{0} \text { Salmo trutta hybrids: } \\
\text { Alta (Norway) } \times \\
\text { Fossbekk (Norway) }\end{array}$ & R. Lierelva & $\mathrm{F}$ & declining after 3 weeks & $\begin{array}{l}\text { innately resistant } \\
\text { and susceptible }\end{array}$ \\
\hline & $\begin{array}{l}\text { JA } \times \text { Q S. trutta hybrids: } \\
\text { Alta (Norway) } \times \\
\text { Fossbekk (Norway) }\end{array}$ & R. Lierelva & $\mathrm{F}$ & elimination in 2 weeks & innately resistant \\
\hline \multirow[t]{5}{*}{ Bakke et al. [26] } & A: Lierelva (Norway) & R. Rauma & A & exponential growth & susceptible \\
\hline & $\begin{array}{l}\text { A: Lierelva and } \\
\text { Batnfjordselva (Norway) }\end{array}$ & $\begin{array}{l}\text { R. Batnfjordselva and } \\
\text { Steinkjerselva }\end{array}$ & $A$ and $A^{*}$ & exponential growth & susceptible \\
\hline & $\begin{array}{l}\text { A: Namsen and Alta } \\
\text { (Norway) }\end{array}$ & R. Lierelva & $\mathrm{F}$ & exponential growth & susceptible \\
\hline & $\begin{array}{l}\text { A } \times \text { B hybrids: } \\
\text { Imsa (Norway) } \times \\
\text { Neva (Russia) }\end{array}$ & R. Lierelva & $\mathrm{F}$ & declining after 4 weeks & responding \\
\hline & B: Neva (Russia) & R. Lierelva & $\mathrm{F}$ & declining after 3 weeks & responding \\
\hline \multirow[t]{2}{*}{ Bakke et al. [66] } & A: Lierelva (Norway) & R. Figga & $A^{*}$ & exponential growth & susceptible \\
\hline & B: Indalsälv (Sweden) & R. Figga & $A^{*}$ & $\begin{array}{l}\text { slightly declining after } \\
4 \text { weeks }\end{array}$ & $\begin{array}{l}\text { responding } \\
\text { and susceptible }\end{array}$ \\
\hline \multirow[t]{2}{*}{ Cable et al. [42] } & A: Alta and Lierelva (Norway) & R. Lierelva & $\mathrm{F}$ & exponential growth & susceptible \\
\hline & B: Neva (Russia) & R. Lierelva & $\mathrm{F}$ & declining after 3 weeks & $\begin{array}{l}\text { innately } \\
\text { resistant } \\
\text { and responding }\end{array}$ \\
\hline \multirow[t]{2}{*}{ Dalgaard et al. [38] } & A: Conon (Scotland) & R. Lærdalselva & $\mathrm{F}$ & exponential growth & susceptible \\
\hline & B: Lule (Sweden) & R. Lærdalselva & $\mathrm{F}$ & declining after 6 weeks & responding \\
\hline \multirow[t]{2}{*}{ Dalgaard et al. [39] } & $\begin{array}{l}\text { A: Conon (Scotland), } \\
\text { Skjern (Denmark) } \\
\text { and Bristol } \\
\text { Cove (Canada) }\end{array}$ & R. Lærdalselva & $\mathrm{F}$ & exponential growth & susceptible \\
\hline & B: Mörrum (Sweden) & R. Lærdalselva & $\mathrm{F}$ & exponential growth & susceptible \\
\hline \multirow[t]{2}{*}{ Jansen et al. [67] } & A: Imsa (Norway) & R. Lierelva & $\mathrm{F}$ & exponential growth & susceptible \\
\hline & $\begin{array}{l}\text { OA } \times{ }^{\wedge} \mathrm{B} \text { hybrids: Imsa } \\
(\text { Norway) } \times \text { Neva (Russia) }\end{array}$ & R. Lierelva & $\mathrm{F}$ & exponential growth & susceptible \\
\hline current study & $\begin{array}{l}\text { A: Dee (Wales), } \\
\text { Lærdalselva (Norway) }\end{array}$ & R. Fusta & A & exponential growth & susceptible \\
\hline
\end{tabular}

Footnotes: ${ }^{1}$ Host response presented using the three categories defined by Bakke et al. [26], i.e. susceptible, responding or innately resistant. *Haplotypes tentatively proposed based on their geographic origin and their relative proximity to defined strains [4]. 
may play a role in extending the infection window for other more susceptible hosts. Given the debate regarding their conspecificity, that G. thymalli exists within the UK and that the UK has been separated from mainland Europe for $\sim 200,000$ years [37], the inclusion and experimental exposure of British T. thymallus to G. salaris was important.

\section{The experimental infection procedure}

The period of experimental exposure used in the current study was $24 \mathrm{~h}$ and follows the methodology used in other G. salaris infection trials $[16,32,42]$. There is, however, no standard exposure period, and the times reported in the scientific literature appear to vary markedly, e.g. $48 \mathrm{~h}$ as used by Jansen et al. [67], Bakke et al. [66] and Dalgaard et al. [39], $72 \mathrm{~h}$ as employed by Bakke and MacKenzie [31], and up to two weeks in the study by Bakke et al. [30]. The experimental exposure period used in the current trial, however, was shown to be effective, resulting in a $100 \%$ prevalence of infection.

\section{Conclusions}

The findings from this trial are significant in that they demonstrate: 1) that Welsh S. salar, as with Scottish S. salar, are also susceptible to G. salaris; 2) that T. thymallus respond in a similar manner to their Scandinavian counterparts and carry infections for up 110 days; and, 3) that English $S$. trutta are responsive to a G. salaris infection, but can harbour infections for longer than those reported for Norwegian populations, i.e. $110+$ days as opposed to 50 days. The differences in S. trutta susceptibility observed in the present study and compared with previous Scandinavian trials $[15,32,33]$, may suggest that potential genetic differences have been accumulated in $S$. trutta strains following their isolation since the last period of glaciation. These extended windows of infection and the interpretation of "resistance" need to be considered carefully in terms of the role that $S$. trutta could play within the context of national management planning and subsequent management in the event of a G. salaris outbreak.

Current national surveillance programmes for G. salaris in the UK focus on areas where $S$. salar are dominant, with relevant sites being sampled on a regular basis, i.e. at least once a year. Other sites, perhaps through limitations of manpower and other resources, are sampled less frequently. The demonstration from this study that G. salaris can persist on $S$. trutta for long periods would suggest that surveillance of $S$. trutta farms and of watercourses inhabited by $S$. trutta, especially where the two salmonids co-exist, should be increased. Given the suggested association of O. mykiss movements and emerging G. salaris infections, it is also recommended that during a suspected outbreak, $S$. trutta in and around $O$. mykiss sites are carefully monitored. While standard operating procedures (SOPs) for the processing and identification of G. salaris were recently addressed by Shinn et al. [76], based on the information from the present study, current national management plans, which already do not allow any fish movements in the event of a suspected outbreak, may benefit from a clarification of the potential role that S. trutta could play in the spread of G. salaris. The findings from this study demonstrate that G. salaris can persist on S. trutta for longer periods than previously thought and that reservoir hosts, such as S. trutta and T. thymallus, for G. salaris may play a more significant role in epidemics than previously believed.

\section{Competing interests}

The authors declare that they have no competing interests.

\section{Authors' contributions}

GP, HH, CFW, NGHT, SH, JEB and APS designed the experimental study. GP, $\mathrm{HH}, \mathrm{CFW}, \mathrm{OLRM}, \mathrm{SJD}, \mathrm{SH}$ and APS performed data collection and analysed the results. GP, HH, CW, NGHT, OLRM, SH, JEB and APS co-drafted the manuscript together. All authors read and approved the final version of the manuscript.

\section{Acknowledgments}

This study was carried out during the tenure of a PhD scholarship from the Department of the Environment, Food and Rural Affairs (Defra), UK (project no. FC1183) awarded to APS and conducted by GP. The authors would like to thank Alan Henshaw, Paddy Mahon and Richard Bond from the Environment Agency, UK for their help with rearing and in the transportation of fish to Norway.

\section{Author details}

${ }^{1}$ Institute of Aquaculture, School of Natural Sciences, University of Stirling, Stirling FK9 4LA, Scotland, UK. ${ }^{2}$ Norwegian Veterinary Institute, Section for Parasitology, P.O. Box 750, Sentrum NO-0106, Oslo, Norway. ${ }^{3}$ Environment Agency, National Fisheries Laboratory, Bromholme Lane, Brampton PE28 4NE, UK. ${ }^{4}$ Centre for Environment, Fisheries \& Aquaculture (Cefas), Weymouth Laboratory, Barrack Road, Weymouth DT4 8UB, UK. ${ }^{5}$ Animal Breeding and Genomics, Animal \& Veterinary Sciences, SRUC, Roslin Institute Building, Easter Bush, Midlothian EH25 9RG, UK. ${ }^{6}$ Fish Vet Group Asia Ltd., 99/386, Chaengwattana Building, Chaengwattana Rd., Kwaeng Toongsonghong, Khet Laksi, Bangkok 10210, Thailand.

Received: 29 June 2014 Accepted: 27 November 2014

Published online: 20 December 2014

\section{References}

1. Harris PD, Shinn AP, Cable J, Bakke TA: Nominal species of the genus Gyrodactylus von Nordmann 1832 (Monogenea: Gyrodactylidae), with a list of principal host species. Syst Parasitol 2004, 59:1-27.

2. Johnsen $\mathrm{BO}, \mathrm{Møk}$ kelgjerd PI, Jensen AJ: The parasite Gyrodactylus salaris on salmon parr in Norwegian rivers, status report at the beginning of year 2000. NINA Oppdragsmelding 1999, 617:1-129.

3. Bakke TA, Cable J, Harris PD: The biology of gyrodactylid monogeneans: the "Russian-doll killers". Adv Parasitol 2007, 64:161-376.

4. Hansen H, Bachmann L, Bakke TA: Mitochondrial DNA variation of Gyrodactylus spp. (Monogenea, Gyrodactylidae) populations infecting Atlantic salmon, grayling, and rainbow trout in Norway and Sweden. Int J Parasitol 2003, 33:1471-1478.

5. Guttvik KT, Moen A, Skår K: Bekjempelse av lakseparasitten Gyrodactylus salaris ved bruk av plantegiften rotenon. Norsk Veterinærtidsskrift 2004, 3:172-174.

6. Rintamäki P: Gyrodactylus salaris at a fish farm in northern Finland. In Parasites of Freshwater Fishes in North-West Europe. Edited by Bauer ON. Petrozavodsk: USSR: Institute of Biology, USSR Academy of Sciences, Karelian Branch; 1989:123-130.

7. leshko E, Berland B, Shulman B, Bristow G, Shchurov I: On some parasites of salmon parr (Salmo salar L., 1758) (Pisces, Salmonidae) from rivers of the Karelian White Sea Basin. In Proc N Int Symp Ichthyoparasitology, $3^{\text {rd }}-7^{\text {th }}$ Oct 1995. Munich, Germany; 1995:100. 
8. Alenäs I: Gyrodactylus salaris på lax i Svenska vattendrag och laxproblematiken på Svenska västkysten. Vann 1998, 1:135-142.

9. Alenäs I, Malmberg G, Carlstrand H: Undersökningar av Gyrodactylus salaris på lax i Ätrans vattensystem, Falkenbergs kommun under fem år 1991-1995. Miljö og Hälsoskyddskontoret Falkenbergs Kommun 1998, 1:1-12

10. Rokicka M, Lumme J, Ziętara MS: Identification of Gyrodactylus ectoparasites in Polish salmonid farms by PCR-RFLP of the nuclear ITS segment of ribosomal DNA (Monogenea, Gyrodactylidae). Acta Parasitol 2007, 52:185-195.

11. Paladini G, Gustinelli A, Fioravanti ML, Hansen H, Shinn AP: The first report of Gyrodactylus salaris Malmberg, 1957 (Platyhelminthes, Monogenea) on Italian cultured stocks of rainbow trout (Oncorhynchus mykiss Walbaum). Vet Parasitol 2009, 165:290-297.

12. Platten M, McLoughlin M, Shinn AP: Distribution and identification of gyrodactylid species in fish farms and rivers in Northern Ireland. Vet Rec 1994, 135:411-412

13. Shinn AP, Sommerville C, Gibson DI: Distribution and characterization of species of Gyrodactylus Nordmann, 1832 (Monogenea) parasitizing salmonids in UK, and their discrimination from G. salaris Malmberg, 1957. J Nat Hist 1995, 29:1383-1402.

14. Mawle GW, Peirson G: Economic Evaluation of Inland Fisheries. Bristol, UK: Managers report from science project SC050026/SR2, Environment Agency; 2009:1-52.

15. Jansen PA, Bakke TA: Susceptibility of brown trout to Gyrodactylus salaris (Monogenea) under experimental conditions. J Fish Biol 1995, 46:415-422.

16. Soleng A, Bakke TA: The susceptibility of grayling (Thymallus thymallus) to experimental infections with the monogenean Gyrodactylus salaris. Int J Parasitol 2001, 31:793-797.

17. Bakke TA, Jansen PA, Kennedy CR: The host specificity of Gyrodactylus salaris Malmberg (Platyhelminthes, Monogenea): susceptibility of Oncorhynchus mykiss (Walbaum) under experimental conditions. J Fish Biol 1991, 39:45-57.

18. Bakke TA, Harris PD, Jansen PA: The susceptibility of Salvelinus fontinalis (Mitchill) to Gyrodactylus salaris Malmberg (Platyhelminthes; Monogenea) under experimental conditions. J Fish Biol 1992, 41:499-507.

19. Bakke TA, Jansen PA, Grande M: The susceptibility of Salvelinus namaycush (Walbaum) to Gyrodactylus salaris Malmberg (Platyhelminthes; Monogenea) under experimental conditions. Fauna Nor (Ser A) 1992, 13:1-7.

20. Bakke TA, Jansen PA, Harris PD: Differences in susceptibility of anadromous and resident stocks of Arctic charr to infections of Gyrodactylus salaris, under experimental conditions. J Fish Bio/ 1996, 49:341-351.

21. Soleng A, Bakke TA: The susceptibility of whitefish (Coregonus lavaretus L.) to experimental infections with the monogenean Gyrodactylus salaris Malmberg, 1957. Bull Scand Soc Parasitol 2001, 11:32-36.

22. Bakke TA, Sharp LA: Susceptibility and resistance of minnows, Phoxinus phoxinus (L.) to Gyrodactylus salaris Malmberg, 1957 (Monogenea) under laboratory conditions. Fauna Nor (Ser A) 1990, 11:51-55.

23. Soleng A, Bakke TA: The susceptibility of three-spined stickleback (Gasterosteus aculeatus), nine-spined stickleback (Pungitius pungitius) and flounder (Platichthys flesus) to the monogenean Gyrodactylus salaris. Parasitol Int 1998, 47:319

24. Bakke TA, Jansen PA, Hansen LP: Experimental transmission of Gyrodactylus salaris Malmberg, 1957 (Platyhelminthes, Monogenea) from the Atlantic salmon (Salmo salar) to the European eel (Anguilla anguilla). Can J Zool 1991, 69:733-737.

25. Bakke TA, Jansen PA, Brabrand A: Susceptibility and resistance of brook lamprey, Lampetra planeri (Bloch), roach, Rutilus rutilus (L.) and perch, Perca fluviatilis L. to Gyrodactylus salaris Malmberg (Monogenea). Fauna Nor (Ser A) 1990, 11:23-26.

26. Bakke TA, Harris PD, Cable J: Host specificity dynamics: observations on gyrodactylid monogeneans. Int J Parasitol 2002, 32:281-308.

27. Peeler EJ, Thrush MA: Qualitative analysis of the risk of introducing Gyrodactylus salaris into the United Kingdom. Dis Aquat Organ 2004, 62:103-113.

28. Peeler EJ, Oidtmann BC: Demonstrating freedom from Gyrodactylus salaris (Monogenea: Gyrodactylidae) in farmed rainbow trout Oncorhynchus mykiss. Dis Aquat Organ 2008, 79:47-56.

29. Thrush MA, Peeler EJ: Stochastic simulation of live salmonid movement in England and Wales to predict potential spread of exotic pathogens. Dis Aquat Organ 2006, 72:115-123.
30. Bakke TA, Jansen PA, Hansen LP: Differences in the host resistance of Atlantic salmon, Salmo salar L., stocks to the monogenean Gyrodactylus salaris Malmberg, 1957. J Fish Biol 1990, 37:577-587.

31. Bakke T, MacKenzie K: Comparative susceptibility of native Scottish and Norwegian stocks of Atlantic salmon, Salmo salar L., to Gyrodactylus salaris Malmberg: Laboratory experiments. Fish Res 1993, 17:69-85.

32. Bakke TA, Soleng A, Harris PD: The susceptibility of Atlantic salmon (Salmo salar L.) $\times$ brown trout (Salmo trutta L.) hybrids to Gyrodactylus salaris Malmberg and Gyrodactylus derjavini Mikailov. Parasitology 1999, 119:467-481.

33. Harris PD, Soleng A, Bakke TA: Increased susceptibility of salmonids to the monogenean Gyrodactylus salaris following administration of hydrocortisone acetate. Parasitology 2000, 120:57-64.

34. Sterud E, Mo TA, Collins CM, Cunningham CO: The use of host specificity, pathogenicity, and molecular markers to differentiate between Gyrodactylus salaris Malmberg, 1957 and G. thymalli Žitňan, 1960 (Monogenea: Gyrodactylidae). Parasitology 2002, 124:203-213.

35. Ståhl G: Genetic population structure of Atlantic salmon. In Population Genetics and Fishery Management. Edited by Ryman N, Utter F. Seattle: University of Washington Press; 1987:121-140.

36. Halvorsen $\mathrm{O}$, Hartvigsen $\mathrm{R}$ : A review of the biogeography and epidemiology of Gyrodactylus salaris. NINA Utred 1989, 2:1-41.

37. Gupta S, Collier JS, Palmer-Felgate A, Potter G: Catastrophic flooding origin of shelf valley systems in the English Channel. Nature 2007, 448:342-345.

38. Dalgaard MB, Nielsen CV, Buchmann K: Comparative susceptibility of two races of Salmo salar (Baltic Lule river and Atlantic Conon river strains) to infection with Gyrodactylus salaris. Dis Aquat Organ 2003, 53:173-176.

39. Dalgaard MB, Larsen TB, Jørndrup S, Buchmann K: Differing resistance of Atlantic salmon strains and rainbow trout to Gyrodactylus salaris infection. J Aquat Anim Health 2004, 16:109-115.

40. Hytterød S, Adolfsen P, Aune S, Hansen H: Gyrodactylus salaris funnet på røye (Salvelinus alpinus) i Fustvatnet (Nordland); patogen for laks (Salmo salar)? Rapp 2011, 11:1-15.

41. Yates DS, Moore DS, Starnes DS: The Practice of Statistics. Third edition. New York, USA: Freeman WH; 2008:1-858.

42. Cable J, Harris PD, Bakke TA: Population growth of Gyrodactylus salaris (Monogenea) on Norwegian and Baltic Atlantic salmon (Salmo salar) stocks. Parasitology 2000, 121:621-629.

43. Gheorghiu C, Cable J, Marcogliese DJ, Scott ME: Effects of waterborne zinc on reproduction, survival and morphometrics of Gyrodactylus turnbulli (Monogenea) on guppies (Poecilia reticulata). Int J Parasitol 2007, 37:375-381.

44. Gheorghiu C, Marcogliese DJ, Scott ME: Waterborne zinc alters temporal dynamics of guppy Poecilia reticulata epidermal response to Gyrodactylus turnbulli (Monogenea). Dis Aquat Organ 2012, 98:143-153.

45. Bridcut EE: A coded alcian blue marking technique for the identification of individual brown trout, Salmo trutta L.: an evaluation of its use in fish biology. Biol Environ Proc R Irish Acad 1993, 93B:107-110.

46. Barber I, Crompton DWT: The distribution of the metacercariae of Diplostomum phoxini in the brain of minnows, Phoxinus phoxinus. Folia Parasitol 1997, 44:19-25.

47. Otranto D, Eberhard ML: Zoonotic helminths affecting the human eye. Parasit Vectors 2011, 4:41.

48. Cox FEG: Immunology. In Modern Parasitology. Third edition. Edited by Cox FEG. Oxford, UK: Blackwell Scientific Publications; 1994:193-218.

49. Price PW: Evolution in parasite communities. Int J Parasitol 1987, 17:209-214.

50. Sukhdeo MVK, Mettrick DF: Parasite behaviour: understanding platyhelminth responses. Adv Parasitol 1987, 26:73-144.

51. Buchmann K, Lindenstrøm T: Interactions between monogenean parasites and their fish hosts. Int J Parasitol 2002, 32:309-319.

52. Van Oosterhout C, Mohammed RS, Hansen H, Archard GA, McMullan M, Weese DJ, Cable J: Selection by parasites in spate conditions in wild Trinidadian guppies (Poecilia reticulata). Int J Parasitol 2007, 37:805-812.

53. Hockley FA, Wilson CAME, Graham N, Cable J: Combined effects of flow condition and parasitism on shoaling behaviour of female guppies Poecilia reticulata. Behav Ecol Sociobiol 2014, 68:1513-1520.

54. Bakke TA: A review of the inter- and intraspecific variability in salmonid hosts to laboratory infections with Gyrodactylus salaris Malmberg. Aquaculture 1991, 98:303-310.

55. Titus RG: Territorial behavior and its role in population regulation of young brown trout (Salmo trutta): new perspectives. Ann Zool Fennici 1990, 27:119-130. 
56. Buchmann K, Uldal A: Gyrodactylus derjavini infections in four salmonids: comparative host susceptibility and site selection of parasites. Dis Aquat Organ 1997, 28:201-209.

57. Olstad K, Cable J, Robertsen G, Bakke TA: Unpredicted transmission strategy of Gyrodactylus salaris (Monogenea: Gyrodactylidae): survival and infectivity of parasites on dead hosts. Parasitology 2006, 133:33-41.

58. Hansen $H$, Bakke TA, Bachmann L: DNA taxonomy and barcoding of monogenean parasites: lessons from Gyrodactylus. Trends Parasitol 2007, 23:363-367.

59. Hansen H, Bakke TA, Bachmann L: Mitochondrial haplotype diversity of Gyrodactylus thymalli (Platyhelminthes; Monogenea): extended geographic sampling in United Kingdom, Poland, and Norway reveals further lineages. Parasitol Res 2007, 100:1389-1394.

60. Hansen H, Martinsen L, Bakke TA, Bachmann L: The incongruence of nuclear and mitochondrial DNA variation supports conspecificity of the monogenean parasites Gyrodactylus salaris and G. thymalli. Parasitology 2006, 133:639-650

61. Meinilä M, Kuusela J, Ziętara MS, Lumme J: Initial steps of speciation by geographic isolation and host switch in salmonid pathogen Gyrodactylus salaris (Monogenea: Gyrodactylidae). Int J Parasitol 2004, 34:515-526.

62. Kuusela J, Holopainen R, Meinilä M, Veselov A, Shchurov IL, leshko EP, Lumme J: Potentially dangerous Gyrodactylus salaris in Russian Karelia: harmless and harmful combinations of host species and parasite strains. In Salmonid Fishes of Eastern Fennoscandia. Petrozavodsk: KarRC RAS; 2005:47-55.

63. Kuusela J, Ziętara MS, Lumme J: Hybrid origin of Baltic salmon-specific parasite Gyrodactylus salaris: a model for speciation by host switch for hemiclonal organisms. Mol Ecol 2007, 16:5234-5245

64. Robertsen G, Hansen H, Bachmann L, Bakke TA: Arctic charr (Salvelinus alpinus) is a suitable host for Gyrodactylus salaris (Monogenea, Gyrodactylidae) in Norway. Parasitology 2007, 134:257-267.

65. Bakke TA, Jansen PA, Saltveit S: Early life survival of wild Atlantic salmon (Salmo salar) experimentally exposed to Gyrodactylus salaris (Monogenea). Parasitol Int 1998, 47:318.

66. Bakke TA, Harris PD, Hansen H, Cable J, Hansen LP: Susceptibility of Baltic and East Atlantic salmon Salmo salar stocks to Gyrodactylus salaris (Monogenea). Dis Aquat Organ 2004, 58:171-177.

67. Jansen PA, Bakke TA, Hansen LP: Resistance to Gyrodactylus salaris Malmberg, 1957 (Monogenea) in Salmo salar: a genetic component. Bull Scand Soc Parasitol 1991, 1:50.

68. Tanum K: Studier av taksonomi og vertsforhold hos Gyrodactylus-arter på laksefisk av slektene Salmo og Salvelinus i Norge. In M.Sc. thesis. Norway: University of Oslo; 1983:1-99.

69. Mo TA: Gyrodactylus-undersokelsene av fisk i forbindelse med rotenonbehandlingen av Skibotnelva i August 1988. Gyrodactylus-undersøkelsene ved Zool Museum Univ i Oslo 1988, 5:1-14.

70. Malmberg G, Malmberg M: Undersökningar angående Gyrodactylus på laxfisk i fria vatten och odlingar under åren 1951-72 Och 1986 - Maj 1991. Inf från Sötvattenlaboratoriet Drottningholm 1991, 2:1-30.

71. Johnsen BO, Jensen AJ: Infection of Atlantic salmon, Salmo salar L., by Gyrodactylus salaris Malmberg 1957, in the River Lakselva, Misvaer in northern Norway. J Fish Biol 1992, 40:433-444.

72. De Roij J, Harris PD, MacColl ADC: Divergent resistance to a monogenean flatworm among three-spined stickleback populations. Funct Ecol 2011, 1:217-226.

73. McHugh ES, Shinn AP, Kay JW: Discrimination of the notifiable pathogen Gyrodactylus salaris from G. thymalli (Monogenea) using statistical classifiers applied to morphometric data. Parasitology 2000, 121:315-323.

74. Shinn AP, Hansen H, Olstad K, Bachmann L, Bakke TA: The use of morphometric characters to discriminate specimens of laboratory-reared and wild populations of Gyrodactylus salaris and G. thymalli (Monogenea). Folia Parasitol 2004, 51:239-252.

75. Fromm B, Burow S, Hahn C, Bachmann L: MicroRNA loci support conspecificity of Gyrodactylus salaris and Gyrodactylus thymalli (Platyhelminthes: Monogenea). Int J Parasitol 2014, 44:787-793.
76. Shinn AP, Collins C, García-Vásquez A, Snow M, Matejusová I, Paladini G, Longshaw M, Lindenstrøm T, Stone DM, Turnbull JF, Picon-Camacho SM, Vázquez Rivera C, Duguid RA, Mo TA, Hansen H, Olstad K, Cable J, Harris PD, Kerr R, Graham D, Monaghan SJ, Yoon GH, Buchmann K, Taylor NGH, Bakke TA, Raynard R, Irving S, Bron JE: Multi-centre testing and validation of current protocols for the identification of Gyrodactylus salaris (Monogenea). Int J Parasitol 2010, 40:1455-1467.

doi:10.1186/s13071-014-0576-5

Cite this article as: Paladini et al.: Reservoir hosts for Gyrodactylus salaris may play a more significant role in epidemics than previously thought. Parasites \& Vectors 2014 7:576.

\section{Submit your next manuscript to BioMed Central and take full advantage of:}

- Convenient online submission

- Thorough peer review

- No space constraints or color figure charges

- Immediate publication on acceptance

- Inclusion in PubMed, CAS, Scopus and Google Scholar

- Research which is freely available for redistribution

Submit your manuscript at www.biomedcentral.com/submit
C Biomed Central 